\title{
Fryderyk Skarbek o konstytucji Królestwa Polskiego z 1815 roku i o statucie organicznym z roku 1832
}

I. Fryderyk Skarbek (1792-1866) pamiętany jest przede wszystkim jako ekonomista, który przeszczepiał na polski grunt liberalne idee Adama Smitha, tworząc na ich bazie pierwszy w polskiej literaturze system ekonomiczny. Był on również po upadku powstania listopadowego i likwidacji Uniwersytetu Warszawskiego, w którym poprzednio wykładał, urzędnikiem w administracji Królestwa Polskiego ${ }^{1}$. Swoje refleksje na temat jego ustroju przedstawił w wczesnych stosunkowo artykułach publicystycznych pochodzących z lat 1818-1821, a następnie - jako historyk dziejów najnowszych - w pisanych na emeryturze dziełach: Dzieje Księstwa Warszawskiego (Poznań 1860), Królestwo Polskie od epoki poczatku swego do rewolucji Listopadowej oraz Królestwo Polskie po rewolucji Listopadowej (publikacja pośmiertna, Poznań 1876-1877), tworzących razem cykl, jak sądzę, nie bez pewnej intencji zatytułowany Dzieje Polski. Sięgnięcie do znajdujących się tam analiz jest interesujące $\mathrm{z}$ dwóch powodów: po pierwsze - zwartych w nich tez, po drugie - dlatego, że pokazują one sposób myślenia pewnej grupy umiarkowanej, liberalnej inteligencji, urzędników czy intelektualistów ze środowisk mieszczańskich i niekiedy szlacheckich.

Publicystyka z lat 1818-1821 pokazuje, że Skarbek postrzegał Królestwo Kongresowe jako odrębny byt państwowy, a podobnie jak wielu przedstawicieli jego środowiska był przekonany o dobrodziejstwach ustroju reprezentacyjnego gwarantowanego konstytucją nadaną przez Aleksandra I w dniu 27 listopada 1815 r. Jego tekst Słowo o wyborach, ogłoszony w uznawanym za liberalne, a nawet nieco opozycyjne, czasopiśmie Brunona Kicińskiego „Orzeł Biały”, wyraża przeświadczenie, że właściwie wybrana Izba Poselska, składająca się z ludzi gotowych do poświęceń dla ojczyzny, jest w sta-

\footnotetext{
${ }^{1}$ Życiorys Skarbka dostępny m.in. w: K. Bartoszyński, S. Kieniewicz, Skarbek Fryderyk Florian (1792-1866), [w:] Polski Stownik Biograficzny, t. 28, Warszawa-Kraków 1997-1998, s. 8-13; K.W. Wójcicki, Fryderyk hr. Skarbek, Warszawa 1873, s. 1-11; P. Mysłakowski, O Autorze i jego Pamiętnikach, [w:] Pamiętniki Fryderyka hrabiego Skarbka, Warszawa 2009, s. 7-19.
} 
nie działać dla dobra ogólnego, współtworząc właściwe prawa². Ten sam wątek powrócił jeszcze w artykule Pan Ignacy, w którym Skarbek ukazał - na zasadzie kontrastu - szanowanego i niewątpliwie zacnego obywatela, który wyłamuje się z udziału w wyborach, uważając je za stratę czasu ${ }^{3}$. Nie ma jednak zupełnie w pismach Skarbka bezkompromisowości kaliszan. Jakkolwiek niewątpliwie Skarbek znał dzieła Benjamina Constanta, brak w jego pismach doktrynerskiego niemal trzymania się tez szwajcarsko-francuskiego myśliciela, jakie przenika poglądy i wypowiedzi kaliszan ${ }^{4}$. Uczony bowiem bardziej postrzegał konstytucję jako gest cesarza Rosji w kierunku Polaków niż - jak zwolennicy Wincentego Niemojowskiego ${ }^{5}$ - jako akt związania się zobowiązaniem zarówno przez obywateli względem władcy, jak i monarchy w stosunku do obywateli. Stąd też w tekście $O$ polityce opublikowanym tuż przed zwołaniem sejmu roku 1820, podczas którego tak gwałtownie ujawniła się opozycja kaliszan, jako najbardziej pożądany wskazywał stan zgodnej współpracy między władcą a parlamentem. Wzywał wobec tego do umiarkowania i spokoju, stwierdzając: „Polityka jest nauką pokoju”6. Skarbek pogląd ów podbudowywał sądem, że sytuacja narodu polskiego po roku 1815 była znacząco lepsza niż na przełomie XVIII i XIX w. - za „czasów pruskich” a więc trzeba było docenić ten porządek, który swoją łaską nadał Aleksander, a nie gonić za ideałem monarchii konstytucyjnej, który w danych okolicznościach był nie do osiągnięcia ${ }^{7}$.

Prowadzoną z dłuższej perspektywy czasowej refleksję nad ustrojem Królestwa Polskiego w okresie autonomii Skarbek zawarł w Królestwie Polskim

\footnotetext{
${ }^{2}$ Y [F. Skarbek], Stowo o wyborach, „Orzeł Biały”, 1820, t. I, nr 4, s. 57-73.

${ }^{3}$ Y [F. Skarbek], Pan Ignacy, „Orzeł Biały”, 1820, t. I, s. 179-185.

${ }^{4}$ Tego, że Skarbek nie traktował rozważań Constanta dogmatycznie, dowodzi artykuł Słowo o władzy wykonawczéy, w którym - wbrew poglądom autora Adolfa wyróżniającego pięć władz - optował za podziałem dychotomicznym na władzę ustawodawczą (zaliczając do niej także monarchę) i wykonawczą. Władzę sądowniczą zaliczył zaś do wykonawczej, ponieważ cel obu tych władz jest taki sam - stosowanie prawa. Trzeba jednak podkreślić, że główna wymowa tekstu jest podobna jak dzieł Constanta, jest nią bowiem dążenie do ograniczenia samowoli władzy wykonawczej. Skarbek wykorzystał pogląd Monteskiusza, że władza sądownicza ma być jedynie „ustami” praw, i rozciągnął go na całą egzekutywę, uznając, że rząd powinien ściśle trzymać się litery ustaw. Por. F. Skarbek, Słowo o władzy wykonawczéy, „Pamiętnik Warszawski”, 1818, t. 10, s. 159-165. Na temat pięciopodziału władz - zob. B. Constant, O monarchii konstytucyynéy i rękoymiach publicznych. Rzecz wyięta $z$ dzieł Benjamina Constanta przekładania Wincentego Niemoiowskiego, Warszawa 1831, część I, s. 58-83.

${ }^{5}$ Por. W. Bortnowski, Walka o cele powstania listopadowego (od 29 listopada $1830 \mathrm{r}$. do lutego 1831 r.), Łódź 1960, s. 18; R.R. Ludwikowski, Główne nurty polskiej myśli politycznej 1815-1890, Warszawa 1982, s. 209-210.

${ }^{6}$ F. Skarbek, O polityce, rzecz czytana na uroczystem posiedzeniu Królewsko-Warszawskiego Uniwersytetu, w przytomności Władz Krajowych, Rektora i Członków tegoż Uniwersytetu, „Orzeł Biały”, 1820, t. VIII, nr 5, s. 49-56; nr 6, s. 59-61; to samo także w zbiorze: Jakiej filozofii Polacy potrzebuja, wybór i wstęp: W. Tatarkiewicz, Warszawa 1970, s. 356.

${ }^{7}$ Por. F. S. [F. Skarbek], List drugi, „Sybilla Nadwiślańska”, 1821, t. I, nr 2, s. 117-131.
} 
od epoki początku swego do rewolucji Listopadowej. W dziele tym - inaczej niż we wcześniejszych artykułach - nie przyznawał Królestwu statusu w pełni niepodległego państwa, acz według niego miało ono cechy państwa. Pisał bowiem, że jego ustrój i ład polityczny nie był oparty na dobrowolnym traktacie, umowie zawartej $\mathrm{z}$ reprezentacją polityczną narodu, lecz nadany z góry. Zresztą uczony dodawał zaraz, że w 1813 r., kiedy wojsko rosyjskie wchodziło do Księstwa Warszawskiego, po stronie Księstwa nie istniała żadna władza, „która by była w prawie zawrzeć i podpisać podobny kontrakt”. Rada Ministrów Księstwa nie miała wszakże kompetencje, by takie posunięcia bez udziału księcia (króla saskiego) przedsięwziąć, a przy tym sama była organem niemającym pełnomocnictwa ze strony narodu, lecz narzuconym w napoleońskiej konstytucji Księstwa z 22 lipca 1807 r. Ten zatem brak właściwej legitymizacji według Skarbka stał na przeszkodzie uznania Królestwa za pełnoprawny organizm państwowy ${ }^{8}$. Dlatego uczony postawił tezę: „Prawa przeto, jakie naród posiadał przed rokiem 1794, przez żadną umowę ani ustępstwo osłabione nie zostały"9. Wypada odnotować, że w poglądach Skrabka na tę kwestię odnaleźć można ślady XVIII-wiecznego dyskursu bazującego na konstrukcji umowy społecznej ${ }^{10}$. Ponadto, ekonomista i historyk jednoznacznie przesądzał kwestię niepodległości Królestwa Polskiego, uznając, że zapis art. 1 konstytucji z 27 grudnia 1815 r. oznaczał, iż „królestwo na zawsze jest przyłączone do cesarstwa Rossyjskiego" "11. Można powiedzieć, że

${ }^{8}$ F. Skarbek, Królestwo Polskie od epoki początku swego do rewolucji Listopadowej, Poznań 1877 , s. $12-13,38$.

${ }^{9}$ Ibidem, s. 38. Warto dodać, że po ten sam argument sięgali po I wojnie światowej polscy prawnicy: Ludwik Ehrlich i Stanisław Hubert, dowodząc, że II Rzeczypospolita weszła w prawa I Rzeczypospolitej na zasadzie ius postlimini, konstrukcji prawnej wziętej od „ojców założycieli” prawa międzynarodowego - Balthasara Ayali (1548-1584), Albericusa Gentilisa (1552-1608) oraz Hugona Grotiusa. Stanisław Hubert podawał, że naród w żaden sposób nie zgodził się na wyzbycie się suwerenności, gdyż traktaty rozbiorowe były nieważne jako zawarte z użyciem fizycznego oraz moralnego nacisku wobec przedstawicieli Rzeczypospolitej uczestniczących w rokowaniach, a kraj znajdował się wtedy pod okupacją i władza nad nim państw zaborczych przez cały okres między 1795 a 1918 r. utrzymywana była wskutek stosowania przymusu; zob. S. Hubert, Odbudowa państwa polskiego jako problem prawa narodów. Odbitka z „Drogi”, Lwów 1934, s. 6; idem, Rozbiory i odrodzenie Rzeczypospolitej (zagadnienia prawa międzynarodowego), Lwów 1937, s. 282 i n.; J. Sondel, Ius postlimini jako podstawa uznania ciagłości I i II oraz II i III Rzeczypospolitej, [w:] M. Marszał, M. Sadowski (red.), Na szlakach Niepodległej. Polska myśl polityczna i prawna w latach 1918- -1939, Wrocław 2009, s. 21-28. Trzeba tutaj wskazać, że tego argumentu Skarbek użył - jak jeszcze zobaczymy - w zupełnie odmiennym celu, a mianowicie, by uzasadnić stanowisko, według którego ustrój konstytucyjny Królestwa Polskiego nie opierał się na zgodzie Polaków, lecz na jednostronnie narzuconej woli cara, którą należało postrzegać jako jego łaskę.

${ }^{10}$ Traktaty zawarte w Wiedniu między Rosją a Prusami oraz Rosją a Austrią w dniu 3 maja 1815 r., dające podstawę prawną do utworzenia Królestwa Polskiego, nazywał Skarbek „czwartym rozbiorem Polski” - F. Skarbek, Królestwo Polskie od epoki początku swego..., s. 20.

11 Ibidem, s. 45; por. ibidem, s. 99-100 (choć nadmienić trzeba, że sam Skarbek przytaczał depeszę lorda Palmerstona z listopada 1831 r., gdzie wyrażono odmienne stanowisko; zob. idem, Królestwo Polskie po rewolucyi Listopadowej, Poznań 1877, s. 29-30). Z taką opinią współcześni 
jego interpretacja statusu Królestwa w znacznej mierze pokrywa się z tą, jaką przedstawił rząd rosyjski w $1833 \mathrm{r}^{12}$

Dzieło Skarbka, jakkolwiek dzisiaj musi uchodzić za anachroniczne, w momencie powstania mogło uchodzić za odpowiedź na tezy zawarte w Powstaniu narodu polskiego w roku 1830 i 1831 Maurycego Mochnackiego; ta praca była wtedy wciąż najobszerniejszym i najbardziej kompleksowym dziełem o powstaniu listopadowym w polskiej literaturze. O ile Mochnacki, zwolennik przecież zbrojnej insurekcji, obstawał przy poglądzie o od początku pozornym i pozoranckim jedynie charakterze swobód zawartych w konstytucji z 1815 r., które w jego przeświadczeniu miały być stopniowo likwidowane ${ }^{13}$, o tyle Skarbek do konstytucji tej podszedł zdecydowanie bardziej poważnie i analitycznie. Dokonał obszernego porównania jej zapisów z postanowieniami konstytucji Księstwa Warszawskiego, szereg zawartych w niej zapisów oceniając - podobnie zresztą jak późniejsi historycy - jako bardziej liberalne od regulacji ustawy zasadniczej z czasów napoleońskich. Wszak - podkreślał - konstytucja Księstwa Warszawskiego ,,przybrała despotyzm w barwę reprezentacyjnego rządu i bawiła nas, jak dzieci, pozorem (...)”. Dość kąśliwie Skarbek stwierdzał, że była ona ,dziwnym połączeniem centralnej administracji francuskiej, z nazwiskami i formami dawnej reprezentacji polskiej, a bez żadnego ograniczenia władzy rządowej, i głównym jej celem było ułatwienia nałożenia na kraj rozkładu podatków na utrzymanie wojska potrzebnych"14. Natomiast konstytucja Królestwa Polskiego znacznie bardziej niż ustawa za-

historycy nie zawsze się zgadzają. Zob. H. Izdebski, Ustawa Konstytucyjna Królestwa Polskiego z 1815 r., [w:] M. Kallas (red.), Konstytucje Polski. Studia monograficzne z dziejów polskiego konstytucjonalizmu, t. I, Warszawa 1990, s. 201-203; jak też rozważania na temat unii polskorosyjskiej w: L. Mażewski, Rzeczypospolita jeden i pót. O narodzinach, istnieniu i upadku państwa polskiego $w$ latach 1806-1831, s. 90-95. Dodać jeszcze trzeba, że Skarbek ponawiane kilkukrotnie obietnice Aleksandra I interpretował nie jako zapowiedź ustanowienia niepodległego państwa obejmującego wszystkie ziemie polskie, lecz jako dążenie do ,połączenia ich wszystkim pod swoje berło" - F. Skarbek, Królestwo Polskie od epoki początku swego..., s. 45. Skoro tak właśnie odczytał stwierdzenia Aleksandra, uczony ten mógł utrzymywać, że cesarz nie był obłudny, gdyż nie obiecywał tworzenia odrębnego państwa czy rozciągnięcia porządku prawnego Królestwa Polskiego na tzw. ziemie zabrane.

12 Idem, Królestwo Polski po rewolucyi Listopadowej..., s. 34-35 (wyjaśnienia rządu rosyjskiego stanowiły odpowiedź na oświadczenia Palmerstona i Roberta Fergussona). Wypada dodać, że Skarbek stanowczo nie zgadzał się z dalszą częścią wywodów strony rosyjskiej, według których sytuacja Królestwa po powstaniu listopadowym nadal pozostawała zgodna z postanowieniami traktatu wiedeńskiego.

${ }^{13}$ Mochnacki przyczyn późniejszego wybuchu upatrywał z jednej strony w poczynaniach wielkiego księcia Konstantego, z drugiej zaś coraz silniejsze w rządzie carskim tendencje do „obskurantyzmu”. Zob. M. Mochnacki, Powstanie narodu polskiego, w r. 1830 i 1831, wyd. II, Wrocław 1840, t. I, s. 157 i n.

${ }^{14}$ F. Skarbek, Królestwo Polskie od epoki początku swego..., s. 55, 56. Z sądem Skarbka zasadniczo zgadzał się młodszy o trzy pokolenia badacz, Władysław Mieczysław Kozłowski (1858-1935); zob. W.M. Kozłowski, Autonomia Królestwa Polskiego (1815-1831), Warszawa 1907, s. 118. 
sadnicza Księstwa dążyła do ograniczenia władzy monarszej, co znajdowało wyraz w obowiązku kontrasygnaty „wszelkich rozkazów i postanowień” króla przez właściwego ministra naczelnika wydziału (art. 47), a także w rozszerzeniu kompetencji prawodawczych sejmu przy jednoczesnym uszczupleniu w tym zakresie uprawnień władcy (art. 90 i 91 konstytucji z 1815 r. w porównaniu z art. 21 konstytucji Księstwa). Przewidywała szerszy katalog praw obywatelskich niż poprzedniczka z czasów napoleońskich, dzięki zabezpieczeniu prawa własności, dając również podwaliny pod rozwój nowoczesnej, towarowo-pieniężnej gospodarki (art. 16-27 konstytucji z 1815 r.). Wreszcie, liberalna tendencja konstytucji Aleksandra wyrażała się w przydaniu religii katolickiej jedynie szczególnej opieki rządu (art. 11) i znacznemu podporządkowaniu hierarchii duchownej władzy świeckiej (przysługujące królowi prawo mianowania wyższych duchownych rozmaitych wyznań - art. 42), podczas gdy art. 1 ustawy zasadniczej Księstwa uznawał ją za „religię stanu”, pozostawiając też odpowiednim władzom duchownym całkowitą swobodę w zakresie obsady istotnych stanowisk kapłańskich ${ }^{15}$. Wskazując liberalne elementy konstytucji Królestwa, Skarbek, podobnie zresztą jak Mochnacki, odmawiał jednocześnie szczerości postępowaniu Aleksandrowi I i europejskich polityków zgromadzonych na kongresie wiedeńskim, określających ramy ustrojowe Królestwa Polskiego: w roku 1815 r., jak pisarz podkreślał,

„(...) piastunowie nasi wypuścili umyślnie z rąk swoich wodze, jakiemi nas kierować mogli, i otworzyli nam od razu szeroki cały zawód życia publicznego, by zdradziecko przypatrywać się temu, jak za wcześnie usamowolnieni nadużyjemy nadanej nam swobody, i rozmyślnie powściągnąć nas wtedy dopiero, gdy już nam sił zabraknie do ocalenia się od upadku"16.

Skarbek zaznaczał przy tym, że rozważana w całości konstytucja ta zawierała w sobie przeciwstawne dążenia. To zaś, niejako niezależnie od rzeczywistych intencji Aleksandra I, musiało doprowadzić do zaburzeń w jej stosowaniu:

„Zamierzała pogodzić udział rządzonych w sprawach pospolitych z jednowładztwem nieograniczonym; kolegialne postępowanie władzy administracyjnej z bezwarunkową uległością urzędników samowolnym rozkazom zwierzchności, wreszcie opozycję reprezentantów narodu z drażliwością najwyższej woli monarchy, zrodzonego do rozkazywania i niemającego żadnego powodu do uwzględniania, mniej więcej słusznych, żądań poddanych" ${ }^{17}$.

\footnotetext{
${ }^{15}$ Por. F. Skarbek, Królestwo Polskie od epoki początku swego..., s. 57-59.

${ }^{16}$ Ibidem, s. XVII. Autor notuje dalej labilne stanowisko Aleksandra I względem przyszłości ziem polskich; zob. ibidem, s. 5, 7 .

${ }^{17}$ Ibidem, s. 56.
} 
W stosunku do ustroju Królestwa Skarbek używał dość dosadnej nazwy: „potwór polityczny”18. Przykładem wewnętrznej niekoherencji ustawy zasadniczej było dla Skarbka chociażby zawarowanie prawa pełnienia funkcji publicznych dla Polaków (art. 29) przy jednoczesnym przyznaniu królowi prawa do dopuszczenia do tychże funkcji „cudzoziemców z zdolności znakomitych" (z wyjątkiem sejmu, do którego dopuszczono wszak książąt krwi cesarskiej - art. 34) ${ }^{19}$. Ponadto zagwarantowano wolność druku - o której nie wypowiadała się zupełnie konstytucja Księstwa - przewidując jedynie wydanie ustawy w celu „ukrócenia jej nadużyciów” (art. 16). Jednak regulacja ta - jak stanowczo zaznacza Skarbek - nie mogła być stosowana bez zastrzeżeń, gdyż ustawa w tej materii, jaką był w stanie zaakceptować sejm, była zawsze z punktu widzenia satysfakcjonująca samodzierżawnego władcy niezadowalająca, a obostrzenia wprowadzone inną drogą prowadzić musiały do naruszenia konstytucji ${ }^{20}$. Ład ustrojowy rozsadzały, zdaniem Skarbka, dwie nowe kompetencje przydane sejmowi: prawo dyskutowania raportu ogólnego Rady Stanu o położeniu kraju (art. 106-107), dające możliwość krytykowania poczynań rządu ${ }^{21}$, oraz prawo petycji, które służyło zgłaszaniu projektów nadzwyczaj odległych linii politycznej egzekutywy. Oba dawały asumpt do dyskusji i żądań, które w danym układzie sił były nie do zrealizowania i mogły jedynie wywołać niezadowolenie władcy. Z kolei przyjęte przez konstytucję głosowanie jawne sprzyjało tworzeniu się opozycji, gdyż wielu posłów i deputowanych, widząc, jakim poparciem cieszyło się stanowisko przeciwne rządowi, do niego przystępowało. Dlatego, jak zaznacza uczony, te właśnie prawa, „mogące jedynie służyć narodowi niepodległemu i samoistnemu”, kłóciły się zdecydowanie „z położeniem od łaski zdobywcy zależącego ludu”. Z tego względu wedle Skarbka bardziej odpowiadała okolicznościom miejsca i czasu konstytucja Księstwa Warszawskiego, która pozwalając na zabieranie głosu w izbie poselskiej wyłącznie członkom Rady Stanu i komisji poselskiej (art. 46), tamowała przejawy walki politycznej na forum parlamentu ${ }^{22}$. Nieodpowiadające sytuacji były również przepisy konstytucji Królestwa dotyczące kompetencji i składu senatu, z jednej strony przyznające mu znacznie szer-

${ }^{18}$ Ibidem, s. 293.

${ }^{19}$ Por. ibidem, s. 58-59.

${ }^{20}$ Ibidem, s. 60. Ograniczenie wolności słowa w Królestwie nastąpiło w 1819 r. w warunkach naruszenia konstytucji, ponieważ przewidziana w art. 16 ustawa nie została wydana (cenzura czasopism została wprowadzona 22 maja, a cenzura książek 16 lipca). Pretekstem do podjęcia tych kroków było zakłócenie porządku w teatrze i dyskusja prasowa wokół wprowadzenia - na rozkaz wielkiego księcia Konstantego - zarządzenia prezydenta Miasta Stołecznego Warszawy o karach policyjnych za głośne zachowanie się podczas widowisk teatralnych; zob. N. Gąsiorowska, Wolność druku w Królestwie Kongresowym 1815-1830, Warszawa 1916, s. 53-73.

${ }^{21}$ Skarbek czynił aluzję do dyskusji nad raportem Rady Stanu podczas sejmu roku 1818. Wówczas krytyczne zdania o polityce rządu przedstawił ks. Adam Czartoryski w uwagach komisji senatu; zob. Dyaryusz Seymu Królestwa Polskiego. 1818, t. III, Warszawa 1818.

${ }^{22}$ F. Skarbek, Królestwo Polskie od epoki początku swego..., s. 61-62. 
sze kompetencje niż miał senat w Księstwie ${ }^{23}$, z drugiej stanowiące, iż król mógł mianować senatorów wyłącznie spośród kandydatów zgłoszonych mu przez samą izbę wyższą, co oznaczało, iż w warunkach występowania w niej opozycyjnych tendencji władca, nie chcąc tracić panowania nad jej decyzjami, był zmuszony złamać konstytucję ${ }^{24}$. Poza tym, inaczej niż w Księstwie ${ }^{25}$, senat otrzymał prawo do publicznego dyskutowania przedkładanych projektów aktów prawnych, a więc z założenia miał mieć pozycję niemal równorzędną izbie poselskiej, i został wyposażony jeszcze w kompetencje do sądzenia - jako sąd sejmowy - zbrodni stanu i przestępstw wyższych urzędników, o których postawieniu przed sądem uprzednio zdecydował ${ }^{26}$. Te wszystkie regulacje powodowały jednak, że pojawiło się nowe forum, na którym głosić można było poglądy opozycyjne ${ }^{27}$. Przy czym Skarbek przede wszystkim, jak trzeba sądzić, czynił aluzję do słynnego sądu sejmowego z roku $1828 \mathrm{r}^{28} \mathrm{Za}$ tak samo nie do pogodzenia $\mathrm{z}$ jedynowładztwem carskim uważał uczony instytucję rad wojewódzkich, które miały przede wszystkim wybierać sędziów dwóch pierwszych instancji, formować listy osób dopuszczonych do sprawowania urzędów i przedstawiać postulaty dotyczące dobra województwa (art. 137). Dlatego zdaniem Skarbka nie może dziwić, że rząd nie pozwolił w pełni realizować kompetencji rad, zwłaszcza gdy chodziło o utworzenie list kandydatów na urzędy i wybór sędziów, a prośby i wnioski dotyczące odnoszące się do projektów, mających służyć dobru województwa, zazwyczaj ignorował ${ }^{29}$. Wreszcie, niezgodna z rzeczywistym dążeniem rządu, była zastrzeżona prawem kolegialność komisji wojewódzkich i ministerstw, która w dużej mierze stawała się fikcją ${ }^{30}$.

${ }^{23}$ Por. 28 konstytucji Księstwa oraz art. 91-92, 95 i 97 konstytucji z 1815 r.

${ }^{24}$ F. Skarbek, Królestwo Polskie od epoki początku swego..., s. 63. Odmiennie konstytucję interpretuje Hubert Izdebski, wskazując, że prawo zgłaszania kandydatów do senatu przysługiwało zarówno senatowi, jak i namiestnikowi; zob. H. Izdebski, Ustawa Konstytucyjna Królestwa Polskiego z 1815 r., s. 207. Różnica wynika stąd, że zapis art. 110 konstytucji stanowił, że Senat przedstawiał królowi kandydatów na senatorów „za pośrednictwem namiestnika”, a według art. 69 ustawy zasadniczej przedstawiał „do nominacji królewskiej podług osobnego urządzenia po dwóch kandydatów na każde wakujące miejsce” w senacie. Z tego ostatniego, dość wieloznacznego artykułu administracja carska wyinterpretowała prawo do samodzielnego przedstawienia cesarzowi kandydatów na senatorów przez namiestnika - i taka też powstała praktyka.

${ }^{25}$ Konstytucja z 22 lipca 1807 r. przydawała senatowi jedynie funkcje kontrolne w procesie legislacyjnym, stanowiąc, że izba wyższa nadawała „sankcję” ustawom uchwalonym przez izbę poselską. Kontrolowanie tego procesu polegało na badaniu zgodności uchwalonego aktu prawnego z przepisami konstytucji, zachowania właściwej procedury oraz tego, czy uchwalane prawo nie godziło w bezpieczeństwo kraju (art. 27-30).

${ }^{26}$ Zob. art. 95, 97, 116 i 152 konstytucji z 1815 r.

${ }^{27}$ F. Skarbek, Królestwo Polskie od epoki początku swego..., s. 64.

${ }^{28}$ Zob. o tym: H. Dylągowa, Towarzystwo Patriotyczne i Sad Sejmowy 1821-1829, Warszawa 1970, s. 214-275.

${ }^{29}$ F. Skarbek, Królestwo Polskie od epoki początku swego..., s. 65-66.

${ }^{30}$ Ibidem, s. 67-68. 
Sprzeczności w samej konstytucji oraz między jej zapisami a rzeczywistym charakterem władzy carskiej przyczyniły się według Skarbka do pojawienia się całkowicie pozakonstytucyjnego ośrodka władzy (,,rządu samowładnego") - hamującego przypisany ustawą zasadniczą liberalizm ustroju - którym stała się grupa wielkiego księcia Konstantego, będącego swoistym alter ego cesarza, oraz senatora Mikołaja Nowosilcowa. Z punktu widzenia rosyjskiego - jak zaznacza Skarbek - potrzeba bowiem było w Królestwie władzy, która byłaby wyższa od namiestnika i

„która by nie wiążąc się żadnemi formami, nie uznając potrzeby szanowania konstytucyi, mogła wykonywać wolę monarchy samowładnie panującego i działać w widokach zasadniczej polityki rosyjskiej i powściągnąc postępki rządzonych przeciwne dążności i woli najwyższej”31.

Porządek konstytucyjny podminowywany był przez to, że oba ośrodki władzy: rząd legalny i władza faktyczna (,rząd samowładny”) podlegały tej samej zwierzchności - osobie cara właśnie. Jednocześnie status prawny władzy wielkiego księcia pozostawał do końca nieuregulowany, ponieważ ujęcie jej w jakieś ramy prawne oznaczały oficjalne zanegowanie przez monarchę nadanej przez siebie konstytucji. Taki stan rzeczy nie tylko nie mógł długo przetrwać, ale musiał wzbudzać niezadowolenie społeczne, które - o czym Skarbek był przekonany - kiedyś musiało wybuchnąc ${ }^{32}$. Uczony zastanawiał się jedynie nad tym, czy niezadowolenie to musiało znaleźć kulminację w powstaniu narodowym, czy też mogło być inaczej skanalizowane. Rozważania Skarbka zawdzięczają wiele XVIII-wiecznej refleksji na temat ustrojów, w tym przede wszystkim koncepcjom Monteskiusza, który twierdzil, że ustrój nielimitowanych rządów jedynowładcy - despotia - realizuje zupełnie inną zasadę niż inne rodzaje ustrojów ${ }^{33}$. Dlatego, jak wskazywał polski uczony, nie można wykreować stabilnej struktury politycznej, częściowo mającej cechy nieograniczonego samowładztwa, a częściowo - ustroju umiarkowanego,

${ }^{31}$ Ibidem, s. 70. Trzeba jeszcze dodać, że uczony bardzo zniuansował swój pogląd o wielkim księciu Konstantym, stwierdzając, że był on połączeniem przeciwieństw - sam miał liberalne poglądy, lecz uważał je za swego rodzaju ,owoc zakazany, którego nikt inny oprócz niego kosztować nie powinien" - ibidem, s. 80. Przeto nie pozwalał, by szerzyły się one wśród jemu poddanych. Co prawda, nie znosił najdrobniejszych oznak nieposłuszeństwa i żądał całkowitej podległości, ale jednocześnie nie dążył do zachowania odrębności od Rosji zarówno polskiego narodu politycznego, jak i administracji Królestwa Polskiego: „(...) nie chciał konstytucyjnego, ale chciał czysto Polskiego królestwa z cesarstwem jednością monarchy połączonego" - ibidem, s. 78-79. O poglądach księcia por. także: idem, Pamiętniki Fryderyka hrabiego Skarbka, opracowanie: P. Mysłakowski, Warszawa 2009, s. 265-266. Z kolei zdecydowanie negatywnie Skarbek ocenił postać Nowosilcowa; zob. idem, Królestwo Polskie od epoki początku swego..., s. 95-97; idem, Pamiętniki Fryderyka hrabiego Skarbka, opracowanie P. Mysłakowski, s. 206.

${ }^{32}$ Idem, Królestwo Polskie od epoki poczatku swego..., s. XVIII; por. ibidem, s. 293.

${ }^{33}$ Zob. Montesquieu, O duchu praw, przekład: T. Żeleński-Boy, Warszawa 1957, t. I, s. 60-62. 
gdyż zasady, na których one bazują, są ze sobą nie do pogodzenia. Taka bowiem mieszanka uniemożliwia wytworzenie się wzajemnej ufności rządzonych i rządzących, który jest niezbędny dla istnienia ustroju konstytucyjnego $^{34}$. Używając - celowo - pewnego pojęciowego anachronizmu, można by stwierdzić, że analizy Skarbka mają charakter bardziej proto-politologiczny niż stricte prawniczy. Doprowadziły one autora do tezy, że konstytucja Księstwa Warszawskiego była lepiej dostosowana do warunków państwa niesamodzielnego niż ustawa zasadnicza z 1815 r., gdyż nie dawała tak wielu sposobności do wystąpień opozycyjnych i podgrzewania przez to nastrojów społecznych $^{35}$. Nie brał jednak pod uwagę, że opozycja polityczna w czasach Księstwa była uśpiona nie tylko z powodu przyjętych rozwiązań ustrojowych, ale także dlatego, że w sytuacji ciągłej wojny albo przygotowań do niej społeczeństwo postrzegało byt państwa za zagrożony i cały wysiłek kierowało w jednym tylko celu - by je zabezpieczyć i rozszerzyćc ${ }^{36}$.

Interpretacje i analizy Skarbka bywają w literaturze krytykowane, gdyż odmawiał on racji opozycji na sejmie Królestwa Polskiego nawet wtedy, gdy jej postulaty były niezbyt daleko idące i uzasadnione. Podstawą bowiem jego rozważań o konstytucji Królestwa była teza, iż należało ją rozumieć jako łaskę cesarza - łaskę, która w dodatku w każdym momencie może być odebrana $^{37}$. W ocenie Skarbka zatem nie należało robić i głosić czegokolwiek, co mogłoby choćby w niewielkim stopniu dawać pretekst do ograniczenia bądź unieważnienia nadanych praw, a już zwłaszcza francuskich teorii liberalnych (mimo że sam cesarz wcześniej był pod ich wpływem). Dlatego krytykował opozycję braci Niemojowskich, uważając, że „nie należało się dopominać tego, o czem naprzód wiedziano, że spełnionem nie będzie, i że upominając się, nie należało używać wyrazów draźliwych pogwałcenia konstytucji”. Z tego punktu widzenia krytykował przebieg pierwszego sejmu z roku 1818, przystając bez większych zastrzeżeń na wyrażane podczas niego stanowisko strony rządowej. Z dobrodziejstwem inwentarza przyjmował choćby przedstawioną w imieniu Aleksandra I interpretację kompetencji izby

${ }^{34}$ Por. F. Skarbek, Królestwo Polskie od epoki początku swego..., s. 106. Skarbek ponadto dowodził, że na przeszkodzie temu obustronnemu zaufaniu władcy i obywateli stała także zadawniona nienawiść Rosjan i Polaków.

${ }^{35}$ Zob. o niej: F. Skarbek, Dzieje Xięstwa Warszawskiego, t. I, Poznań 1860, s. 131-133.

${ }^{36}$ Chociaż o nastrojach społecznych w Księstwie Warszawskim pisze sam Skarbek - zob. ibidem, t. I, 155-164; ibidem, t. II, s. 276-290, passim. Ponadto portret tamtych czasów i panujących wtedy postaw przedstawił Skarbek w swej beletrystyce; zob. idem, Pamiętniki Seglasa, opracowanie K. Bartoszyński, Warszawa 1959, s. 190 i n. Z kolei poświęcenie polskich żołnierzy w armii napoleońskiej uhonorował w zborze opowiadań Powiastki polskie, Poznań 1861.

${ }^{37}$ Zdaniem Skarbka ten charakter konstytucji ujawnił się po uzupełnieniu jej o artykuł dodatkowy w roku 1825. Jeżeli bowiem cesarz „mógł wyrzec przed całym światem, że zamyka drzwi izby poselskiej, ażeby głosy jej członków nie zyskiwały poklasku publiczności, mógł podobnież zamknąć na zawsze podwoje sejmowe, aby do nich i samych reprezentantów nie wpuścić" F. Skarbek, Królestwo Polskie od epoki poczatku swego..., s. 181. 
poselskiej, która zawężała jej prawo do dyskusji (wynikające z art. 154 statutu organicznego o reprezentacji narodowej), według której izba powinna skupić swoją uwagę na konkretnych propozycjach dotyczących dyskutowanej materii, a nie artykułowaniu ,jedynie zasad ogólnych i owych teoretycznych badań" ${ }^{38}$. Twierdził też, że w roku 1818 sejmowi liberałowie bez żadnej potrzeby składali petycję w sprawie wydania ustawy zabezpieczającej wolność druku przed samowolą władz administracyjnych, albowiem ,nie było jeszcze cenzury, ani żadnych nadużyć tej wolności”. Dodawał ponadto, że specjalna ustawa dotycząca gwarancji tej wolności „nie mogła być żadną rękojmią, skoro sama ustawa konstytucyjna podobnej rękojmi pozbawiona była"39. Władysław Mieczysław Kozłowski, słusznie krytykując kapitulancki ton wypowiedzi Skarbka i ich nadmierną uległość, odpierał jego argumenty, wskazując, że przecież „narzucenie cenzury w r. 1819 było uczynione pod pozorem braku prawa, zabezpieczającego od nadużyć prasowych" ${ }^{40}$. W podobny sposób podważyć można również niektóre inne tezy Skarbka.

Skarbek poddawał krytyce nie tylko stanowisko opozycji politycznej Królestwa Polskiego, ale także działania Rosjan. Uważał, że po to, aby utrzymać Polaków w ryzach, Aleksander nie powinien był tworzyć konstytucyjnego quasi-państwa z pozornymi prawami politycznymi (takim bowiem tworem w przekonaniu Skarbka było Królestwo Kongresowe), lecz nie składając żadnych dalej idących obietnic, nadać „,autonomię wewnętrzną”, a więc swoisty samorząd, wszystkim częściom dawnej Polski, które znalazły się pod berłem carskim. Cesarz mógłby scalić te części w jeden twór administracyjny, ale według Skarbka nie było to konieczne. Nadmieniał przy tym, że takie rozwiązanie nie wzbudziłoby takiej niechęci Rosjan wobec Polaków, jak powołanie do życia Królestwa Polskiego, którego mieszkańcy mieli znacznie większe prawa od innych poddanych cara $^{41}$. Komentując wywody uczonego, przytaczany już Władysław Mieczysław Kozłowski nie bez pewnej słuszności stwierdzał, że żądanie nadania wszystkim mieszkańcom dawnej Rzeczypospolitej takich samych praw wynikało stąd, iż:

„Dla Skarbka, jak i dla całego pokolenia, do którego należał, »prawa historyczne« narodu polskiego stanowiły pewnik niezachwiany. Granice tradycyjne Rzeczypospolitej stanowiły dla wszystkich Polaków owej doby kres ludów objętych węzłem jednej narodowości (...)"42.

${ }^{38}$ Ibidem, s. 142.

${ }^{39}$ Ibidem, s. 143.

${ }^{40}$ W.M. Kozłowski, op. cit., s. 148.

${ }^{41}$ F. Skarbek, Królestwo Polskie od epoki początku swego..., s. 293-295. Zob. też uwagi Lecha Mażewskiego, Rzeczypospolita jeden i pół..., s. 106-107, który nadmienia, że realizacja propozycji Skarbka mogłaby doprowadzić do zmiany charakteru imperium rosyjskiego, umożliwiając jego ewolucję w kierunku federacji.

${ }^{42}$ W.M. Kozłowski, op. cit., s. 214. 
Uwaga ta nie wyczerpuje całej istoty zagadnienia. Postulat objęcia autonomią wszystkich obywateli dawnej Rzeczypospolitej rzeczywiście oparty jest na pojęciu ,praw historycznych”, jednak pogląd Skarbka, że utrzymanie Polaków w posłuszeństwie wymagało temperowania ich roszczeniowych postaw i nieprzyznawania im nadmiernych praw, staje się w pełni zrozumiały dopiero przy uwzględnieniu specyficznej refleksji tego uczonego o psychologii narodowej - refleksji, dodajmy, nie do końca dającej się pogodzić z koncepcją ,praw historycznych”.

Otóż Skarbek wykazywał, że obywatele Księstwa Warszawskiego nie byli dawnymi Polakami, ale członkami nowego narodu, który wytworzył się pod wpływem wojen napoleońskich jedynie na bazie narodu szlacheckiego I Rzeczypospolitej. Młodość tego narodu przypadła zaś na okres Królestwa. Skarbek formułował przy tym historiozoficzną nieledwie tezę, iż narody przeżywają, tak jak ludzie, okres dzieciństwa, młodości i dojrzałości, którym odpowiadają specyficzne cechy charakteru ${ }^{43}$. Stąd charakter zbiorowy Polaków Królestwa był wypadkową niektórych dawnych cech (np. braku rozsądku politycznego) i wad młodości, takich jak zapalczywość czy niecierpliwość ${ }^{44}$. Wobec tego potrzebowali takich instytucji politycznych, które by nakładały kaganiec na ich emocje i roszczenia i w efekcie pozwoliły wejść narodowi w stateczny wiek dojrzałości. Ponieważ takich instytucji zabrakło, więc będąc pozbawieni umiejętności właściwego osądu sytuacji, Polacy dali asumpt do odebrania sobie tego wszystkiego, co wcześniej wywalczyli ${ }^{45}$.

\section{Fryderyka Skarbka ocena sytuacji publicznoprawnej Królestwa} Polskiego. Po przegranej wojnie z Rosją w 1831 r. i na gruncie statutu organicznego z 1832 r. Skarbek - jako referendarz zwyczajny w Radzie Stanu i członek Dyrekcji Szpitali i Więzień - rozkazem cesarskim wezwany został do Petersburga w celu zapoznania się z tamtejszymi szpitalami i instytucjami

${ }^{43} \mathrm{O}$ problemach intelektualnych, które niesie ze sobą ,ppsychologia narodowa” Skarbka, zob.: A. Wierzbicki, Historiografia polska doby romantyzmu, Wrocław 1999, s. 448-473; idem, Spory o polska duszę. Z zagadnień charakterologii narodowej $w$ historiografii polskiej XIX i XX wieku, Warszawa 2010, s. 148-151. Wydaje się, że cykl historycznych prac Skarbka właśnie z tego powodu otrzymał tytuł Dzieje Polski, że miał ukazywać losy tego nowego narodu polskiego.

${ }^{44}$ F. Skarbek, Królestwo Polskie od epoki początku swego..., s. XIII-XVIII.

${ }^{45}$ Podobny nieco pogląd wyrażał Kajetan Koźmian, który tak samo jak Skarbek wskazywał, że konstytucja z 1815 r. była łaską monarchy (każdą zresztą konstytucję oktrojowaną można postrzegać w taki sposób), a także utrzymywał, iż miała ona nazbyt liberalny charakter w kontekście ówczesnych realiów społeczno-kulturowych, do których znacznie lepiej była dopasowana konstytucja Księstwa Warszawskiego. Uzasadniał ten sąd jednak trochę inaczej niż Skarbek, podkreślając, że tak liberalne instytucje prowokują do uaktywnienia się wpisanego głęboko tkwiących w charakterze Polaków ,anarchiczności” i warcholstwa. Por. K. Koźmian, Pamiętniki, Wrocław-WarszawaKraków-Gdańsk 1972, t. III, s. 40-41, 47; J. Bartyzel, Kajetan Koźmian - protokonserwatysta epoki Królestwa Polskiego do 1830 r., [w:] L. Mażewski (red.), System polityczny, prawo i konstytucja Królestwa Polskiego 1815-1830, Radzymin 2013, s. 311-314. 
dla ubogich i potrzebujących. Na miejscu znalazł się w końcu października 1830 r., wobec czego - niejako przypadkiem - obserwował gorący okres powstania listopadowego z punktu widzenia cesarstwa. Skarbek oceniał powstanie zasadniczo negatywnie, jako nieprzygotowany i zdecydowanie przedwczesny - realizowany bez planu i przywództwa - zryw wywołany przez tzw. stronnictwo ruchu, a więc - według słów uczonego - ,zapalonych i niecierpliwych”, którzy zdominowali „umiarkowanych” i „rozsądnych”. Natomiast gdy powstanie już wybuchło, zdaniem tego ekonomisty i historyka należało zasadniczo realizować scenariusz zbieżny z tym, o jakim myślał wtedy książę Adam Czartoryski, tzn. wzmacniać siły zbrojne i nie unikać konfrontacji militarnej, a po jednym czy kilku zwycięstwach rozpocząć z cesarzem korzystne rokowania, które skończyłyby się rozszerzeniem Królestwa o część przynajmniej ziem zabranych oraz gwarancjami utrzymania w nim ustroju konstytucyjnego ${ }^{46}$. Scenariusz ten jednak, wskutek sporów, błędów i - jak nadmieniał Skarbek - ,zdrad" nie został zrealizowany.

Przebywając na dworze cesarskim, Skarbek jednocześnie pozostawał nadal w administracji. Mając o nim pozytywne zdanie, Mikołaj I powołał go do Rady Tymczasowej (Rządu Tymczasowego Królestwa Polskiego), która miała być swoistym rządem tymczasowym Królestwa, obejmującym władzę na terytorium zajmowanym przez wojska rosyjskie. W Radzie tej objął funkcję dyrektora wyznań i oświecenia publicznego, co łączyło się z tytułami szambelana i radcy stanu nadzwyczajnego $0^{47}$. Jak sam po latach stwierdzał, broniąc się przed zarzutem kolaboracji, przyjął to stanowisko, gdyż cesarz wskazał, że nie będzie musiał sprzeniewierzyć się interesom Polakom:

„Miałem pracować nad zagładzeniem śladu nieszczęść przez kraj doznanych i w tym posłannictwie miałem tak postępować, jak prawemu Polakowi przystoi. Sumienie moje jest mi świadkiem, żem nie zboczył nigdy z drogi, jaką mi sam Cesarz w chwilowym wspaniałomyślnym natchnieniu wskazał, i że wtenczas zaraz postanowiłem zrzec się choćby największej dostojności, jeżelibym kiedykolwiek od tej raz przyjętej zasady odstąpić znalazł się zmuszonym" ${ }^{\text {"48 }}$.

${ }^{46}$ Por. F. Skarbek, Rewolucya Listopadowa, Ossolineum, rps sygn. 5530/III, k. 51-73 (fragment ten nie wszedł do żadnej z publikowanych prac historycznych Skarbka). Za błąd dyktatora Chłopickiego uznał Skarbek zarówno unikanie walki, jak zwołanie sejmu.

${ }^{47}$ Inne funkcje objęli: rzeczywisty tajny radca Fiodor Engel jako prezes, Roman Fuhrman - dyrektor Wydziału Przychodów, Skarbu i Kontroli, gen Aleksander Strogonow - dyrektor Wydziału Spraw Wewnętrznych i Policji oraz gen. Franciszek Ksawery Kossecki - dyrektor Wydziału Sprawiedliwości. Większość składu Rady stanowili zatem nie-Polacy (Rosjanie oraz znajdujący się w służbie carskiej Niemcy). Zob. F. Skarbek, Królestwo Polski po rewolucyi Listopadowej..., s. 6.

${ }^{48}$ F. Skarbek, Pamiętniki Fryderyka hrabiego Skarbka, opracowanie. P. Mysłakowski, s. 259; podobnie: F. Skarbek, Dziennik podróży do Petersburga 1830. Autograf, Ossolineum, rps, sygn. 5528/I, k. 1-2. Cesarz miał powiedzieć do Skarbka: „wiem, że jest pan dobrym Polakiem, i właśnie dlatego pana wybrałem". Trzeba jednak pamiętać, że Skarbek pisał swe wspomnienia od razu z za- 
Na rozkaz cara udał się do Królestwa, lecz gdy przybył do Warszawy, polityka cara uległa zmianie i jego nominację do Rady Tymczasowej anulowano, a stanowisko, które miał objąć, otrzymał gen. Józef Rautenstrauch. Sam uczony pisał, że stało się tak wskutek tego, że po śmierci gen. Dybicza umiarkowane stronnictwo niemieckie utraciło swoje wpływy, na znaczeniu zyskało zaś „czysto rosyjskie” stronnictwo, którego przedstawicielem był gen. Paskiewicz, a z którego polityką powierzenie funkcji ministra Skarbkowi nie mogło być zgodne ${ }^{49}$. Być może zresztą do Petersburga dotarły jakieś informacje o kłopotach z cenzurą Królestwa byłego profesora Uniwersytetu Warszawskiego, a także o posądzeniu go o kontakty z Towarzystwem Patriotycznym, W związku z czym jego postawę uznano za zbyt liberalną ${ }^{50}$. W służbie carskiej pozostał jednak nadal. Nim rozważymy, co go do tego skłaniało, należy przyjrzeć się temu, jak oceniał zmiany statusu publicznoprawnego Królestwa, które się wówczas dokonywały.

Skarbek oceniał, że przeobrażenie rządu i publicznoprawnej podstawy jego funkcjonowania zmierzały w kierunku usankcjonowania samowoli Rosji. Pierwszym ich przejawem było to, że Rząd Tymczasowy pod przewodnictwem Fiodora Engla (ten sam, do którego miał wejść Skarbek) - „na jakiem takiem legalnem postępowaniu oparty" - otrzymał zwierzchnictwo gen. Iwana Paskiewicza, któremu tymczasem nadano tytuł księcia warszawskiego. Było to zdaniem Skarbka sygnałem, że

„wkrótce zwiniętym i zastąpionym zostanie samowolą i nieograniczoną władzą naczelnego dowódcy siły zbrojnej, który upoważniony do tego przez cesarza, za

miarem ich publikacji (jakkolwiek miało to nastąpić dziesięć lat po jego śmierci), wobec czego swoje decyzje przedstawiał w taki sposób, by je pokazać opinii publicznej w jak najkorzystniejszym świetle. Dlatego tego typu świadectwa trzeba traktować z odpowiednią dozą krytycyzmu.

${ }^{49}$ F. Skarbek, Królestwo Polski po rewolucyi Listopadowej..., s. 7; idem, Pamiętnik podręczny. Zeszyt 2, Ossolineum, rps, sygn. 5522/I, k. 7-8.

${ }^{50}$ Kierownik cenzury Królestwa, Józef Kalasanty Szaniawski, twierdził już w 1820 r., że pisma Skarbka miały zbyt liberalny charakter. Starcie z cenzorem miało miejsce na tle publikacji przez Skarbka Elementarnych zasad gospodarstwa narodowego, które to dzieło zostało zgłoszone przez autora, uznającego autonomię szkoły wyższej, wyłącznie do cenzury uniwersyteckiej, jedynie do cenzury uniwersyteckiej, uznając funkcjonowanie autonomii uniwersytetu. W odpowiedzi Szaniawski wysłał do Petersburga nieprzychylny raport dotyczący tej książki. Zob. K. Bartoszyński, O powieściach Fryderyka Skarbka, Warszawa 1963, s. 42; J. Bieliński, Królewski Uniwersytet Warszawski, t. II, Warszawa 1911, s. 440-445. Natomiast w 1826 r. Skarbek był przesłuchiwany w ramach śledztwa przeciwko członkom Towarzystwa Patriotycznego, lecz żadnych zarzutów nie usłyszał. Zresztą nie istnieją żadne dowody potwierdzające jego członkostwo w Towarzystwie. Sam zaś przyznawał się w pamiętnikach tylko do uczestnictwa w kilku tajnych spotkaniach. Jednakże według Józefa Korpały, który przenalizował nieopublikowany pamiętnika złożony w „tekach Walewskiego" (biblioteka PAN i PAU w Krakowie), Skarbek miał należeć w roku 1820 do Związku Młodych Polaków; zob. F. Skarbek, Pamiętniki Fryderyka hrabiego Skarbka, opracowanie P. Mysłakowski, s. 218-220; J. Korpała, Za kulisami młodej Warszawy literackiej przed powstaniem listopadowym, „Pamiętnik Literacki”, 1931, z. 4, s. 563-564. 
jej pomocą dokona wszystko, co zamyśli i co za potrzebne uzna dla upokorzenia i ujarzmienia mieszkańców kraju (...)"51.

Wszystko to oznaczało przyjęcie zasady podlegania władzy cywilnej pod władzę wojskową. Pierwszym zaś symptomem ,zamiaru zniweczenia znamion narodowości Polskiej” było zastąpienie - mocą wydanego bez podstawy prawnej reskryptu Paskiewicza - polskiej kokardy i barw kokardą i barwami Rosji ${ }^{52}$. Przyjmował zatem, iż to śmierć gen. Dybicza i utrata wpływów przez stronnictwo niemieckie zapoczątkowały odmianę polityki cara (było to zgodne z przekonaniem Skarbka o rzeczywistej, choć szkodliwej, nienawiści między narodami polskim i rosyjskim). Trzeba odnotować, że późniejsi historycy przyjmowali inną wersję wydarzeń. Władysław Bortnowski, powołując się na korespondencję Mikołaja I z Dybiczem, wskazał, iż car już na przełomie stycznia i lutego 1831 r. miał zamiar powołać namiestnika z tytułem generał gubernatora (zostałby nim Dybicz) i zaprowadzić okupację wojskową, jeśliby doszło do otwartej walki ${ }^{53}$. Tym samym wskazuje się na to, że zamiary cara co do przyszłości Królestwa skrystalizowały się już w pierwszych dwóch miesiącach $1831 \mathrm{r}$.

Skarbek stanowczo utrzymywał, że statutu organicznego z 14 (26) lutego 1832 r. cesarz ,prawdopodobnie wykonać nawet nie zamierzał”, a ten akt prawny powstał jedynie po to, aby uspokoić opinię publiczną Europy, żądającą respektowania zapisów traktatu wiedeńskiego dotyczących Polaków ${ }^{54}$. Przytoczył ponadto treść manifestu Mikołaja I ogłoszonego wraz ze statutem, głoszącego, że ustrój Królestwa będzie oparty na takich zasadach, jakie są do

51 F. Skarbek, Królestwo Polski po rewolucyi Listopadowej..., s. 8-9. Warto nadmienić, że postać Paskiewicza Skarbek oceniał tak samo jednoznacznie, jak osobę wielkiego księcia Konstantego. Otóż uznawał, że książę warszawski zwłaszcza w latach 40. i 50. XIX w. chronił pozostałości autonomii Królestwa przed dążeniem administracji petersburskiej do całkowitego ich skasowania, dążąc tym samym do utrzymania swojej władzy i pozycji. Zob. ibidem, s. 76-78; idem, Pamiętniki Fryderyka hrabiego Skarbka, opracowanie P. Mysłakowski, s. 342-345. Można nawet wskazywać, że figury Konstantego i Paskiewicza pełnią w narracji Skarbka tę samą funkcję: są to bowiem Rosjanie, którzy nie mają zamiaru sprzyjać dobru narodu polskiemu, ale ich prywatny interes w pewnym momencie zaczął się z tym dobrem splatać. Intencją Skarbka było, jak się zdaje, pokazanie, że rozsądek polityczny nakazywał wchodzenie niekiedy w swoiste alianse strategiczne z takimi ludźmi i wykorzystywanie ich przez Polaków do własnych celów.

52 Idem, Królestwo Polski po rewolucyi Listopadowej..., s. 12-13.

53 W. Bortnowski, Powstanie listopadowe w oczach Rosjan, Warszawa 1964, s. 80 (z powołaniem na: Vojna s polskimi mjateżnikami v perepiske imperatora Nikolaja Pavlovicza s grafom Dibiczom, „Russkaja Starina”, t. 41, 1884, s. 108-109, 380-382, 388). Władysław Zajewski podaje z kolei - niestety bez dokładnego podania źródła - jakoby w styczniu 1831 r. Mikołaj I podjął decyzję, by przekształcić Królestwo Kongresowe w prowincję Rosji, nawet jeżeli polska armia dobrowolnie i zupełnie by skapitulowała; zob. W. Zajewski, Walki wewnętrzne ugrupowań politycznych w powstaniu listopadowym, Gdańsk 1967, s. 108, 114.

${ }^{54}$ F. Skarbek, Królestwo Polski po rewolucyi Listopadowej..., s. 15, 19. Pełny tekst statutu organicznego - zob. M. Handelsman, Konstytucje polskie 1791-1921, Warszawa 1922, s. 100-109. 
pogodzenia „z potrzebami i dobrym bytem” cesarstwa. Zatem zapewni się odrębną administrację Królestwa, lecz w taki sposób i w takim zakresie, by „nie przestało nigdy być stanowczo nierozerwalną częścią cesarstwa Rossyjskiego (...)”. Według Skarbka manifest ten właśnie zapowiadał - bardziej niż statut organiczny - unifikację Królestwa Kongresowego z Rosją ${ }^{55}$.

Sam statut organiczny zawierał, co prawda, w pierwszym tytule zagwarantowanie odrębności prawodawstwa (art. 1, zdanie drugie) oraz skarbu Królestwa (art. 16), jak również pozostawienia dotychczasowych podatków (art. 15), a także szeregu praw i wolności jednostki: wolności wyznania z uwzględnieniem szczególnej opieki nad wyznaniem rzymskokatolickim (art. 5), równości wobec prawa „bez żadnej różnicy stanu lub znaczenia” i - związanej z nią - równości w ubieganiu się o urzędy i godności (art. 7), wolności osobistej każdego wraz z zakazem aresztowania i oddania pod sąd poza prawem wskazanymi przypadkami (art. 8), poszanowania prawa własności prywatnej, które uznano za „święte i nietykalne” (art. 11), wreszcie zaś wolności druku $\mathrm{z}$ takimi jedynie ograniczeniami, jakie będą konieczne „do zapewnienia winnego uszanowania dla religji, nietykalności władzy najwyższej, nieskazitelności obyczajów i osobistego honoru każdego" ${ }^{\text {"56 }}$. Jednakże ponieważ statut przyznawał obywatelom Królestwa Polskiego więcej praw, niż mieli poddani na terytorium Cesarstwa Rosyjskiego, w przekonaniu Skarbka „przewidzieć już wtenczas można było, że ten statut nie wejdzie w wykonanie: bo prawa, które przyznawał Polakom, (...) były przeszkodą w przeprowadzeniu głównego zamiaru zrobienia z nich i Rossyan jednego braterskiego ludu"57. Uczony podawał przy tym konkretne przykłady lekceważenia wymienionych regulacji, jak chociażby kasata „zbytecznych” klasztorów katolickich będąca specyficznym przejawem zawarowanej statutem organicznym „opieki i protekcji rządu" dla Kościoła katolickiego ${ }^{58}$. Nie miał on zatem żadnych złudzeń, jeśli chodzi o trwałość praw przyznanych statusem organicznym.

Skarbek wykazywał, że określone w tytule drugim władze Królestwa pod względem organizacji wewnętrznej w znacznym stopniu odpowiadały tym, jakie istniały przed $1830 \mathrm{r}$., z pewnymi wszakże modyfikacjami, mającymi na celu ujednolicenie administracji w Królestwie i w Cesarstwie. Rada Administracyjna miała podobną organizację, jak w poprzednim okresie, i tak samo miała prawo przedstawiania kandydatur na wyższe stanowiska duchowne i urzędy, lecz car zapewniał sobie prawo do powołania na nie osób nieprzedstawionych przez Radę (art. 26 statutu). Także Rada Stanu została wyposażona $\mathrm{w}$ kompetencje podobne do tych, jakie miała przed powstaniem. Unifikacja administracji i prawodawstwa przejawiała się jednak w tym, że istotne

\footnotetext{
${ }^{55}$ F. Skarbek, Królestwo Polski po rewolucyi Listopadowej..., s. 17-18.

${ }^{56}$ Por. M. Handelsman, Konstytucje polskie 1791-1921 ..., s. 100-102.

${ }^{57}$ F. Skarbek, Królestwo Polski po rewolucyi Listopadowej..., s. 18-19.

${ }^{58}$ Ibidem, s. 26.
} 
uprawnienia prawodawcze w odniesieniu do Królestwa otrzymała Rada Stanu Cesarstwa Rosyjskiego, w której utworzono odrębny Departament Interesów Królestwa Polskiego (jak wskazuje Skarbek - choć to wprost nie wynika z przepisu art. 31 statutu - mający składać się w połowie z Polaków i w połowie z Rosjan). Poza tym, zamiast dotychczasowych czterech komisji rządowych, utworzono trzy, materię oświaty łącząc ze sprawami wewnętrznymi (art. 35). Jak wskazywał Skarbek, rozwiązanie takie pozwalało przypuszczać, ,że ważna gałęź, dotycząca oświecenia, nie zostanie pod władzą administracji krajowej"59.

Skarbek najbardziej krytycznie odniósł się do tytułów III i IV statutu organicznego, nazywając je fikcjami, obejmującymi „same złudzenia polityczne, o których nicości każdy po krótkim namyśle powinien był się przekonać". Zgromadzenia szlacheckie i gminne, które na mocy art. 43-44 dyskrecjonalnie zwoływać miał namiestnik, nazywał urągowiskiem ,dawnych sejmików i zgromadzeń gminnych, jakie obierały posłów i deputowanych do Sejmu". Pozostałe zapisy tego tytułu uważał Skarbek za zupełnie puste i nic nie znaczące sformułowania. Jak bowiem podkreślał, skoro w latach 1815-1830, mimo określonych w konstytucji (art. 137) analogicznych kompetencji, rady wojewódzkie nie wybierały sędziów, a formowane przez nie listy kandydatów na urzędy oraz postulaty dotyczące dobra województwa nie miały żadnego praktycznego znaczenia, trudno było przypuszczać, że w nowej rzeczywistości politycznej instytucje te nabiorą większego znaczenia. Wzmiankowane w tytule IV zgromadzenia stanów prowincjonalnych, które miały wypowiadać się z głosem doradczym „w interesach pod rozwagę im podawanych” przez rząd (art. 53), nazywał instytucjami, jakie ustanowiono tylko po to, aby ich nie wprowadzać w życie ${ }^{60}$. Ponadto - zaznaczał uczony - nie stwierdzono nigdzie wprost uchylenia konstytucji z 1815 r., ale słowa manifestu Mikołaja sugerowały, że buntując się i nadużywając praw, obywatele Królestwa swoimi rękami ją „obalili”. Z kolei art. 69 statutu mówił jedynie ogólnie o „skasowaniu” wszystkich wcześniejszych praw ,sprzeciwiających się przepisom niniejszego statutu organicznego"61. Car nie zdobył się nawet na otwarte pozbawienie konstytucji mocy obowiązującej ${ }^{62}$. Według Skarbka otwarte złamanie postanowień statutu organicznego, gwarantujących wolność osobistą, nastąpiło wraz z wydaniem ukazu carskiego z 11 (22) kwietnia 1833 r., przydające namiestnikowi kompetencję do wskazania czynów będących zbrodniami sta-

\footnotetext{
${ }^{59}$ Ibidem, s. 20.

${ }^{60}$ Ibidem, s. 21.

${ }^{61}$ Ibidem, s. 18, 22; M. Handelsman, Konstytucje polskie 1791-1921 ..., s. 109.

${ }^{62}$ Historyk i ekonomista dodawał, że co prawda statut organiczny był powszechnie odczytywany nie jako łaska, lecz kara nałożona na naród, który się zbuntował, nie podejrzewano jednak, że jego zapisy będą od samego początku martwe, a rząd Królestwa będzie mieć „najsamowładniejszy” charakter; por. F. Skarbek, Królestwo Polski po rewolucyi Listopadowej..., s. 22.
} 
nu, które tym samym podlegać miały kognicji sądów wojennych, przy czym od wyroków tych sądów nie przysługiwało prawo łaski ${ }^{63}$. Od tego momentu nie istniała, jego zdaniem, w Królestwie realna ochrona życia, wolności i mienia - wartości, które dlań, jako dla liberała, miały podstawowe znaczenie.

III. Zamiast zakończenia. Pod interpretacjami konstytucji Aleksandra, statutu organicznego z 1832 r. i ocenami publicznoprawnego statusu Królestwa Polskiego po kongresie wiedeńskim, jakie Skarbek przedstawił, równie dobrze mogłyby podpisać się radykalny zwolennik insurekcji ${ }^{64}$. Wszak uczony stanowczo zaznaczał, że Królestwo Polskie nie było faktycznie państwem niepodległym, konstytucja była wyrazem łaski samodzierżawcy, jaką władca mógł cofnąć, a niektóre postanowienia nie miały być nigdy wykonane. $\mathrm{Z}$ kolei statut organiczny według Skarbka był aktem przede wszystkim propagandowym, nastawionym na wzbudzenie w międzynarodowej opinii publicznej przekonania, że prawa obywateli Królestwa są nadal przestrzegane, prawdziwym zaś zamiarem cara była pełna unifikacja administracji tych ziem z Cesarstwem. Trzeba zatem odpowiedzieć na pytanie, dlaczego mimo tak krytycznej oceny publicznoprawnej sytuacji Królestwa, Skarbek - po pierwsze - zdecydował się pozostać na służbie w administracji, a po drugie - cały czas konsekwentnie opowiadał się za postawą lojalistyczną.

Można by próbować tłumaczyć postawę Fryderyka Skarbka, odwołując się do jego sytuacji osobistej. Wiadomo wszakże, iż rodzinny majątek został w dużej mierze zaprzepaszczony przez jego ojca, Kaspra Skarbka, którego wystawny styl życia i wielkopańskie nawyki doprowadziły do ogromnego zadłużenia $^{65}$. Dlatego płatna posada była dla uczonego źródłem stałego dochodu i umożliwiała mu życie na poziomie odpowiadającym jego statusowi. Zamknięcie Uniwersytetu Warszawskiego po upadku powstaniu spowodowało, że stracił stanowisko profesora ekonomii politycznej i związane z nim niemałe wynagrodzenie. W tej sytuacji wybór zapewniającej stałą pensję kariery urzędniczej dla człowieka mającego bardzo dużą teoretyczną i praktyczną wiedzę o administrowaniu był dość naturalny. Dodać trzeba, że pozwolono mu zajmować się tym, co go autentycznie interesowało jeszcze przed powstaniem, a więc problematyką więziennictwa i pomocy społecznej ${ }^{66}$. Poprzesta-

63 Ibidem, s. 46-48. Uczony dodawał, że asumpt do wprowadzenia tych przepisów dała działalność emisariuszy emigracyjnych, którą uznał za szkodliwą. Wspominał też o planach powstańczych Józefa Zaliwskiego; zob. ibidem, s. 4-45.

${ }^{64}$ Por. też uwagi Joachima Lelewela o konstytucjach z 1807 i 1815 r. - J. Lelewel, Trzy konstytucje polskie 1791, 1807 i 1815, Warszawa 1831, s. 58, 60, 63-64, 83-84.

65 Żeby uratować choć cząstkę majątku przed wierzycielami, matka Fryderyka musiała przeprowadzić rozwód, ojciec zaś uciekł za granicę. Zob. F. Skarbek, Pamiętniki Fryderyka hrabiego Skarbka, opracowanie P. Mysłakowski, s. 38-42.

${ }^{66}$ Został członkiem, a od 1845 r. prezesem Rady Głównej Opiekuńczej Instytutów Dobroczynnych. 
nie na takim wyjaśnieniu wydaje mi się jednak mocno niepełne, by nie powiedzieć, że nazbyt trywialne.

Pełniejszą odpowiedź może dać sięgnięcie do rozważań historycznych Skarbka. Otóż utworzenie Królestwa Polskiego połączonego unią z Rosją było dlań mniejszym złem niż podział Księstwa Warszawskiego wzdłuż dawnych granic trzeciego zaboru, co oznaczałoby ,żywioł niemiecki posunąć ku Wiśle"67. Uczony sugerował, że z uwagi na układ sił geopolitycznych Królestwo Polskie pod berłem cara było jedyną opcją, która mogła być po upadku Napoleona zrealizowana. Ponadto jego zdaniem Aleksander I, dzięki ustanowionym przez siebie instytucjom, ,przyczynił się do utrzymania i wzmocnienia ducha narodowego" "68. Skarbek doceniał to, że rząd rosyjski do $1830 \mathrm{r}$. nie prowadził żadnych działań zmierzających do wzmocnienia żywiołu rosyjskiego w Królestwie - pozwalał rozwijać edukację w języku polskim, nie wspierał prawosławia, nie wprowadził do urzędów języka rosyjskiego, wreszcie pozostawił odrębne wojsko polskie ${ }^{69}$. Wszystko to przyczyniało się do zachowania „narodowości” mimo braku w pełni niepodległego państwa.

Źródłem i podstawą tych wszystkich sądów i ocen jest pojęcie narodu, którym operował uczony. Pojęcie to zdaje się spajać wszystkie analizy Skarbka w jeden obraz, a jego przeanalizowanie umożliwia też lepsze zrozumienie postawy ekonomisty i historyka. Otóż naród w ujęciu Skarbka jest kategorią zawierającą zarówno element etniczny, jak i polityczny, który jest co najmniej równie ważny jak ten pierwszy. Uczony uznał, jak za Johannem Gottfriedem Herderem bardzo wielu jemu współczesnych, że naród w sensie etnicznym budowany jest przez język, wspólne tradycje i obyczaje ${ }^{70}$. Jednocześnie wskazywał, że tak rozumiane narody tworzą szersze wspólnoty ludów o tym samym pochodzeniu i zbliżonych cechach, przede wszystkim językach. Wspólnoty te zresztą są niejednokrotnie wzajemnie skonfliktowane, jak na przykład Germanie i Słowianie. Właśnie nienawiść Niemców do tego, co słowiańskie, powodowała zdaniem Skarbka, że podejmowali oni na ziemiach włączonych po trzecim zaborze do państwa pruskiego powolną, acz konsekwentną akcję wynaradawiającą ${ }^{71}$. Stąd uczony był przekonany, że dążenia Niemców są znacznie groźniejsze dla Polaków niż działania Rosjan, co stanowiło też je-

\footnotetext{
${ }^{67}$ Idem, Królestwo Polskie od epoki początku swego..., s. 32.

${ }^{68}$ Ibidem, s. 44-46.

${ }^{69}$ Por. ibidem, s. 100-102, 104-105.

${ }^{70}$ Niekiedy zresztą, mając na myśli takie rozumienie narodu, uczony stosuje takie terminy, jak ,plemię” czy „szczep”.

${ }^{71}$ Idem, Dzieje Xięstwa Warszawskiego, t. I, Poznań 1860, s. X, 14, 28 (tutaj m.in. o wprowadzeniu języka niemieckiego jako urzędowego); idem, Gospodarstwo narodowe stosowane, czyli zasady nauki gospodarstwa narodowego zastosowane do praktyki. Znajomość kraju - rolnictwo, Warszawa 1860, s. 62-63. Uczony nie bierze pod uwagę, że z punktu widzenia scentralizowanej monarchii absolutnej w modelu pruskim jeden język urzędowy i ujednolicone procedury oraz prawo materialne były elementami koniecznymi dla właściwego działania administracji.
} 
den z argumentów na rzecz lojalności wobec cara ${ }^{72}$. Skarbek podkreślał, że aby jednak mówić o narodzie w pełnym tego słowa znaczeniu - a więc będącym nie tylko bytem kulturowym, ale również „ciałem politycznym” - musi oprócz więzi etnicznej istnieć jakaś postać politycznej reprezentacji - element obywatelski ${ }^{73}$. Jeżeli nie ma tej reprezentacji, własnych instytucji prawnopolitycznych i choćby ograniczonej możliwości decydowania o swoich sprawach wewnętrznych, naród może w ogóle zniknąć ${ }^{74}$. Jeden z najbardziej zasłużonych badaczy problematyki, Andrzej Walicki, słusznie uwypuklał fakt, że w polskiej myśli politycznej obywatelski aspekt pojęcia narodu, wytworzony w I Rzeczypospolitej i rozwinięty w okresie Oświecenia, przeniknął do koncepcji doby romantyzmu ${ }^{75}$. Aspekt ten występuje też u Skarbka, tyle że ten stateczny i umiarkowany klasycysta wykorzystywał go w inny sposób niż romantycy. Dla niego własne instytucje i reprezentacja polityczna nie musiały oznaczać pełnej niepodległości, do utrzymania „narodowości” wystarcza według niego znaczna autonomia ${ }^{76}$. Jak się zdaje, te właśnie poglądy na za-

72 Skarbek wyraźnie bolał nad tym, że Polacy i Rosjanie nie mogli dojść do porozumienia w okresie Królestwa Konstytucyjnego, porozumienie takie bowiem stworzyłoby istotną siłę przeciwko napierania pierwiastka germańskiego; zob. szkic - idem, Jaka mogła bydź przyszłość Kr. Pol., a jaka była, Ossolineum, rps 5522/I, zeszyt I, k. 82-84.

${ }^{73}$ Zob. definicje w: idem, Elementarne zasady gospodarstwa narodowego, t. I, Warszawa 1820, s. 7; idem, Ogólne zasady nauki gospodarstwa narodowego, czyli czysta teorya ekonomii politycznéj, t. II, Warszawa 1859, s. 8. Zob. też Duch Narodowy i Kosmopolityzm, „Orzeł Biały”, 1820 , t. IV, nr 3 (6 kwietnia), s. 40-43 (Joanna Nowak przypisuje ten niepodpisany artykuł Skarbkowi; zob. J. Nowak, Duchowe piętno społeczeństw: złożoność i przeobrażenia polskiej refleksji nad narodem w XIX wieku, Warszawa 2008, s. 29).

${ }^{74}$ Wydaje się, że właśnie z uwagi na zupełnie odbiegające od dotychczasowej tradycji instytucje polityczne Skarbek traktował obywateli Księstwa Warszawskiego (a potem Królestwa Kongresowego) jako naród nowy (rozumiany jako naród polityczny). Kategoria narodu jest zatem też podstawą rozważań uczonego o charakterze Polaków, o których już była mowa.

${ }^{75}$ Zob. A. Walicki, Idea narodu w polskiej myśli oświeceniowej, Warszawa 2000, s. 10, 107 i n.

${ }^{76}$ Rozwijana przez Skarbka idea narodu stanowi recepcję i rozwinięcie koncepcji Stanisława Staszica, który zwłaszcza po 1815 r. formułował koncepcję „szczepów” - słowiańskiego, germańskiego i „Gaulolatyńskiego" - będących swoistymi jednostkami wyższymi od narodów; zob. S. Staszic, Myśli o równowadze politycznej w Europie czytane w Wydziale Literatury Towarzystwa Przyjaciól Nauk w roku 1815 w miesiącu sierpniu, [w:] idem, Pisma filozoficzne i społeczne, PWN [Warszawa] 1954, t. II, s. 301-321; A. Walicki, op. cit., s. 78-82; T. Matlęgiewicz, Wokót problematyki narodu w pismach Stanisława Staszica, „Studia Politicae Universitatis Silesiensis”, 2011, t. 7, s. 15-39; idem, Program słowiański Stanisława Staszica po postanowieniach kongresu wiedeńskiego, „Przegląd Nauk Historycznych”, 2011, r. X, nr 1, s. 190-191, 193-199. Uwagę o tym zawdzięczam Tomaszowi Matlęgiewiczowi, któremu pragnę w tym miejscu gorąco podziękować. Warto nadmienić, że Skarbek był dość bliskim współpracownikiem Staszica w ostatnich latach życia tego uczonego, a apologię jego działalności na rzecz poprawy położenia chłopów zawarł w odrębnej rozprawie, co tłumaczy wpływ Staszica na Skarbka; zob. F. Skarbek, Rosprawa o dobroczynnym zakładzie dla rolników w Królestwie Polskim, „Roczniki Towarzystwa Królewskiego Warszawskiego Przyjaciół Nauk", 1824, t. XVII, s. 148-164. Choć trzeba dodać, że Skarbek odrzucał znaczną część filozofii dziejów Staszica, uznając ją za dziwaczną i wprowadzając w to miejsce własne, dużo prostsze historiozoficzne konstrukcje. Zob. uwagę o poemacie Ród ludzki idem, Pamiętniki Fryderyka hrabiego Skarbka, opracowanie P. Mysłakowski, s. 185-186. Ponadto 
chowanie narodu polskiego skłoniły Skarbka do tego, by w roku 1861 - gdy otrzymał propozycję zasiadania w Radzie Stanu Królestwa Polskiego - uzależniać swoją zgodę od przyjęcia przez rząd carski organu opiniodawczego dla Królestwa o składzie wyłanianym w wyborach pośrednich, mającego wypowiadać się na temat przedkładanych mu aktów prawnych ${ }^{77}$. Myśliciel ten dodawał, że odrodzenie państwa polskiego z uwagi na szczupłość zasobów materialnych i moralnych nie było możliwe siłami krajowymi, lecz wymagało wystąpienia sprzyjającej sytuacji międzynarodowej ${ }^{78}$. Stąd był on przekonany, że nie można było pozwolić sobie na jakieś gesty czy działania, które dawały pretekst carowi do znacznego uszczuplenia bądź nawet skasowania i tak słabego bytu politycznego Polaków, jakim było Królestwo Polskie. Gdyby bowiem tak się stało, w przekonaniu Skarbka istnienie narodu polskiego byłoby tak samo zagrożone, jak pod panowaniem pruskim po roku $1795^{79}$. Dlatego odrzucał wszelkie działania zmierzające do powstania, uważając, że mogą one jedynie pogorszyć sytuację. Z kolei swój udział w administracji Królestwa uznawał jednocześnie, jak się wydaje, za pracę na rzecz zachowania politycznej odrębności narodu polskiego ${ }^{80}$.

wydaje się uprawniona teza, że w pojęciu narodu stosowanym przez Skarbka znacznie bardziej niż u późnego Staszica podkreślony jest element polityczny.

77 Zob. na ten temat: J. Bardach, Zabiegi Fryderyka Skarbka i jego projekt ciała opiniodawczego z 1861 roku, „Przegląd Historyczny”, 1977, t. LXVIII, z. 4, s. 699-706 (tam też przygotowany przez Skarbka w języku francuskim projekt aktu prawnego w tej sprawie).

${ }^{78}$ Zob. F. Skarbek, Królestwo Polskie od epoki początku swego..., s. 310-311.

${ }^{79} \mathrm{O}$ upadku narodu ,pod panowaniem pruskim” - zob. idem, Dzieje Xięstwa Warszawskiego, t. I, Poznań 1860, s. 129-130.

${ }^{80} \mathrm{O}$ polskich urzędnikach administracji Królestwa nie był zresztą najlepszego zdania, twierdząc, że ulegali deprawacji pod wpływem Rosjan, z którymi pracowali, i ,tracili po trochu poczucie obowiązków swoich względem narodu" - idem, Królestwo Polski po rewolucyi Listopadowej..., s. 93. 